Harvard Kennedy School Misinformation Review ${ }^{1}$

December 2020, Volume 1, Issue 8

Creative Commons Attribution 4.0 International (CC BY 4.0)

Reprints and permissions: misinforeview@hks.harvard.edu

DOI: https://doi.org/10.37016/mr-2020-50

Website: misinforeview.hks.harvard.edu

\title{
Conspiracy and debunking narratives about COVID-19 origins on Chinese social media: How it started and who is to blame
}

This paper studies conspiracy and debunking narratives about the origins of COVID-19 on a major Chinese social media platform, Weibo, from January to April 2020. Popular conspiracies about COVID-19 on Weibo, including that the virus is human-synthesized or a bioweapon, differ substantially from those in the United States. They attribute more responsibility to the United States than to China, especially following Sino-U.S. confrontations. Compared to conspiracy posts, debunking posts are associated with lower user participation but higher mobilization. Debunking narratives can be more engaging when they come from women and influencers and cite scientists. Our findings suggest that conspiracy narratives can carry highly cultural and political orientations. Correction efforts should consider political motives and identify important stakeholders to reconstruct international dialogues toward intercultural understanding.

Authors: Kaiping Chen (1), Anfan Chen (2), Jingwen Zhang (3), Jingbo Meng (4), Cuihua Shen (3)

Affiliations: (1) Life Sciences Communication, University of Wisconsin-Madison, USA, (2) Science Communication and Science Policy, University of Science and Technology, China, (3) Department of Communication, University of California, Davis, USA, (4) Department of Communication, Michigan State University, USA

How to cite: Chen, K., Chen, A., Zhang, J., Meng, J., \& Shen, C. (2020). Conspiracy and debunking narratives about COVID-19 origins on Chinese social media: How it started and who is to blame. Harvard Kennedy School (HKS) Misinformation Review, 1(8).

Received: August $11^{\text {th }}, 2020$. Accepted: November $13^{\text {th }}, 2020$. Published: December $10^{\text {th }}, 2020$.

\section{Research questions}

- Content. What conspiracy narratives on the origins of COVID-19 are prevalent on Chinese social media over different outbreak phases? How are they similar or different from conspiracy narratives popular in the United States? According to these conspiracies, which countries/entities are to blame for the origins of the COVID-19 pandemic?

- Engagement. What kind of social media users help propagate conspiracy and debunking posts, and how do they engage with these posts? What debunking strategies are more successful in engaging users?

\footnotetext{
${ }^{1}$ A publication of the Shorenstein Center for Media, Politics and Public Policy, at Harvard University, John F. Kennedy School
} of Government. 


\section{Essay summary}

- We used the largest-to-date COVID-19 Weibo corpus to understand the prevalent conspiracy and counteractive narratives regarding COVID-19 origins, through different phases of the pandemic from January 1 to April 30, 2020.

- Popular conspiracies about COVID-19 on Weibo differ substantially from those in the United States. Conspiracies about COVID-19 as human-synthesized or a bioweapon are prevalent on Weibo, especially following Sino-U.S. confrontations.

- Most conspiracy posts on Weibo faulted the United States for COVID-19 origin, whereas most debunking posts sought to absolve China from responsibility.

- Debunking conspiracies can be more engaging when they come from women and influencers and cite scientific sources.

\section{Implications}

COVID-19 has garnered a massive number of conspiracy narratives on social media since January 2020. Conspiracy refers to "an effort to explain some event or practice by reference to the machinations of powerful people, who attempt to conceal their role" (Sunstein \& Vermeule, 2009, p. 205). In the COVID19 context, conspiracy centers around virus origination (i.e., who created and spread it). Such misbelief can erode institutional trust, dampen international relations, generate xenophobia, or decrease preventive health behaviors (Swire-Thompson \& Lazer, 2020). Conspiracy narratives have been examined in the United States (Mitchell et al., 2020; Silver et al., 2020) and in Europe (Georgiou et al., 2020). For example, prominent narratives promote conspiracy ideation that the U.S. government created the virus, the virus is a Chinese bioweapon (Jamieson \& Albarracin, 2020), 5G spreads COVID-19 (Ahmed et al., 2020), or Bill Gates was behind the virus for vaccination programs (Georgiou et al., 2020). So far, no study has examined the evolution of conspiracy narratives in China. Understanding variations of conspiracy narratives across different sociopolitical contexts is imperative in correcting such misinformation and is pivotal in building effective transnational cooperation to mitigate the pandemic.

This study focuses on the Chinese social media context, which, against a backdrop of escalating SinoU.S. conflicts, has fostered various COVID-19 conspiracies that present a different picture from that of the United States and the globe. We examined social media posts that propagate and debunk COVID-19 conspiracies. This paper defines conspiracy posts as those that spread conspiracies about the origins of COVID-19. This paper defines debunking posts to broadly include any posts that disprove, disagree with, or refute such conspiracies, either with or without providing evidence (see Appendix $G$ for examples of conspiracy posts and debunking posts). The debunking posts were classified by their content and not restricted to any particular type of user or source. Overall, our findings suggest three important real-world implications.

The first key implication is that political parties, media, and public agencies should avoid purposefully or inadvertently propagating conspiracy narratives, as they not only misdirect the public's attention during a public health crisis but can also breed long term harm such as declining trust towards governments and authorities (Freeman et al., 2020). Our findings suggest conspiracy narratives were a direct response to the deteriorating Sino-U.S. relationship, and in turn, debilitated the relationship even further, creating a precarious downward spiral. Conspiracies either covertly or overtly endorsed by the two countries' political figures have exacerbated the problem and devastated international collaborations for global pandemic responses.

Further, pandemic and conspiracy narratives carry highly contextualized cultural and political assumptions and nuances (Ding \& Zhang, 2010; Jovančević \& Milićević, 2020). As we show, prominent 
conspiracies about the origins of COVID-19 center on either human synthesis or biological weapons on Weibo. By contrast, popular conspiracies concerning 5G, Dr. Fauci, and Bill Gates in the United States and elsewhere are seldom mentioned on Weibo. Underlying the differences in conspiratorial arguments are different cultural and political orientations toward technology and government. For example, Chinese nationalism in the posts in portraying the United States as a political and economic threat fuels the bioweapon conspiracy. Correcting such conspiracies thus requires further addressing constructed nationalism. A practical implication is that efforts to mitigate conspiracy narratives need to work on increasing intercultural and international dialogues to identify common interests and values, and to dispel unfounded claims and misunderstandings. In this regard, we suggest government agencies, media, and educators work on developing more constructive and unbiased narratives of the pandemic and its global responses.

The second implication informs governmental policy on fighting against the susceptibility to conspiracy beliefs. Just as most conspiracy posts on Weibo faulted the United States for originating COVID19 , most debunking posts sought to absolve China from responsibility. The finding suggests that people may selectively endorse and share debunking messages that support their own group, resulting in an ideologically narrow flow of debunking messages to their followers (Shin \& Thorson, 2017). Against the backdrop of increasing Sino-U.S. tension, it is challenging to engage the public when debunking certain conspiracy narratives consistent with one's political or national identity. Communication strategies thus need to facilitate dissolving echo chambers around certain conspiracy narratives that politicize health issues (Del Vicario et al., 2016). For example, inoculation could be an effective strategy to reduce the public's susceptibility to conspiracy beliefs (Roozenbeek \& van der Linden, 2019). By giving small doses of conspiracy narratives and explicitly warning the public about how specific political motives (e.g., partisanship, international conflict) fuel each conspiracy narrative, we could help the public become more sophisticated at processing various information on social media.

A final implication of this study concerns platform design around creating effective debunking strategies to counteract conspiracy posts. We showed that users were less engaged (i.e., less likely to retweet, like, comment) in debunking posts than conspiracy posts, which echoes previous work that false information is distributed significantly faster, farther, and more broadly than true information on social media (Vosoughi et al., 2018). Fighting conspiracy is a difficult battle, but our study highlights that influencers and verified organizational users with a larger following could help draw more user participation to debunking posts. Influencers and organizational users can be considered as critical seeds for disseminating debunking information through online social networks (Rubin, 2017). Social media platforms and public agencies may consider actively enlisting their help in the debunking process.

In sum, we propose the following practical recommendations:

- Political parties, media, and public agencies should avoid citing nationalistic and politically motivated conspiracy narratives and make an effort to dispel conspiracy thinking through increased international dialogues.

- Public communication efforts can consider employing inoculation and media literacy education to decrease susceptibility to conspiratorial thinking.

- Social media platforms need to encourage trusted influencers, organizations, and scientists to disseminate debunking information.

\section{Findings}

Finding 1: Popular conspiracies about the origins of COVID-19 on Chinese social media differ remarkably from those in the United States. Conspiracies about COVID-19 as human-synthesized or bioweapon are 
prevalent on Weibo, and these posts attribute more responsibility to the United States than to China.

Figure 1 shows the number of posts that attribute responsibility to the United States, China, and other entities for each origin type and responsibility attribution comparing conspiracy posts vs debunking posts. We found that conspiracy origin types that dominate the Chinese social media differ from those in the United States and around the globe. In the United States or around the globe, conspiracy about 5G, Dr. Fauci, and Bill Gates are prevalent (Goodman \& Carmichael, 2020; Mitchell et al., 2020). These conspiracies, however, constitute a small proportion of conspiracies on Weibo (4.95\%). Prevalent conspiracies on Weibo focus on whether COVID-19 was deliberately made by country actors in labs or as bioweapons.

Comparing the attribution of responsibility between debunking posts and conspiracy posts, we found that people were more likely to debunk conspiracies that blame China while propagating conspiracies that blame the United States more frequently $\left(\chi^{2}=564.29, p<0.01\right)$. Responsibility attribution to the United States and China also substantially differed between conspiracies about the natural/unknown origin of COVID-19 versus those about the deliberate formation of COVID-19. For conspiracy posts expressing belief that the origin of COVID-19 is natural/unknown, responsibility was attributed more frequently to China (31.07\%) than those stating that COVID-19 was deliberately synthesized by humans (15.36\%) or used as bioweapons (4.20\%).

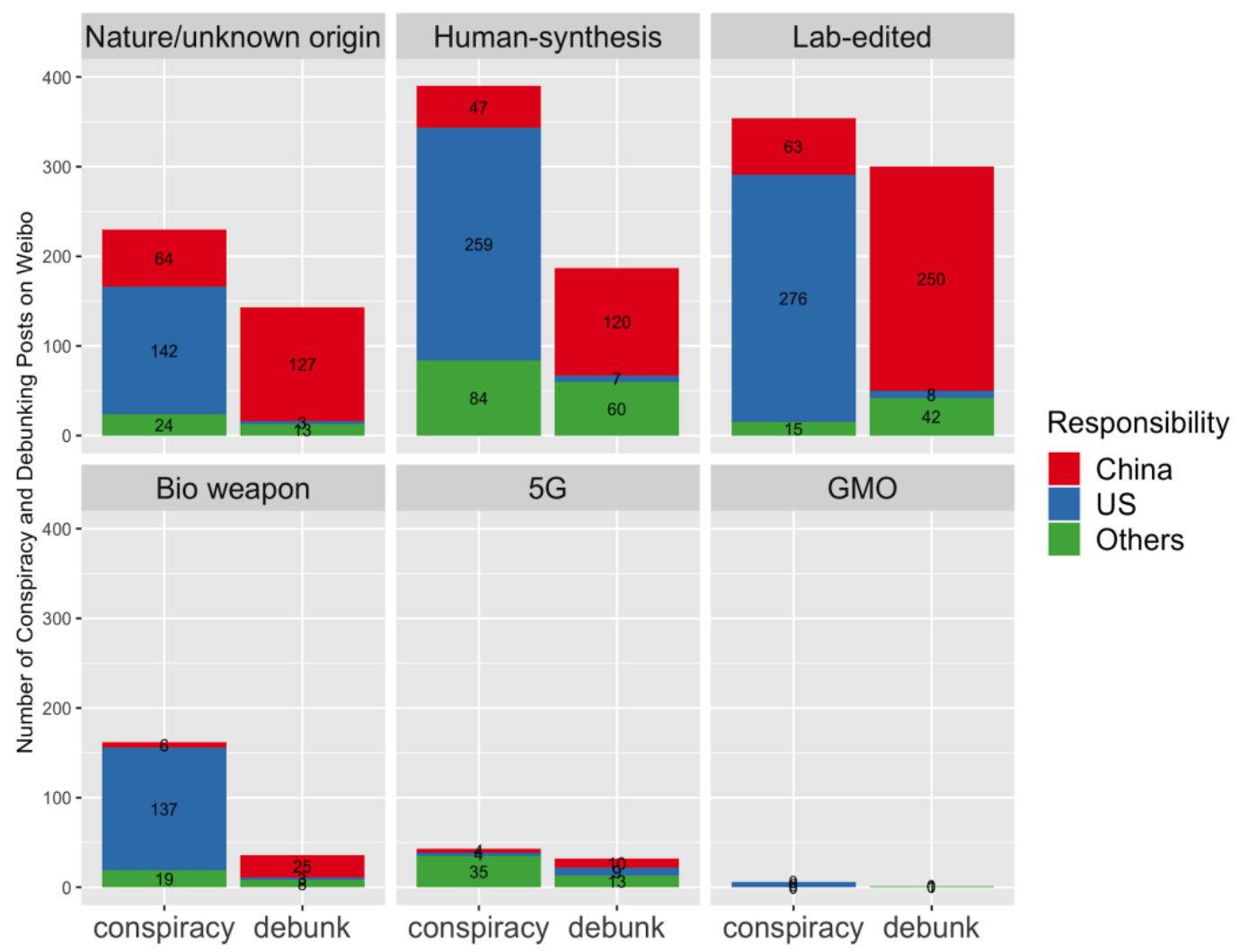

Figure 1. Number of conspiracy and debunking posts by Covid-19 origins type and responsibility attribution.

Finding 2: Conspiracies that blamed the United States for COVID-19 surged following Sino-U.S. conflicts.

Conspiracy and debunking narratives, as well as responsibility attribution, evolved over time with an interesting pattern. Conspiracy posts surged when President Trump first referred to the coronavirus as 
the China Virus and announced sanctions on China such as the green card ban and the $5 \mathrm{G}$ cleaning plan on Huawei. While conspiracy posts surged during times of Sino-U.S. conflict, debunking posts surged when China's cases surged around mid-February due to changes in diagnosis testing and when Trump said he would stop using the term China Virus on March 24, 2020 (Figure 2, top panel). This pattern of how Weibo posts evolved with Sino-U.S. conflict also persisted in terms of responsibility attribution of COVID-19. We found that posts that attribute responsibility to the United States for creating COVID-19 virus surged during times of Sino-U.S. conflict (Figure 2, bottom panel).

These findings on how conspiracies and responsibility attribution evolved with Sino-U.S. conflict underscore the pandemic as a catalyst for geopolitical conflicts, nationalism, and misinformation. Our findings echo the recent literature stressing that nationalism might harm the equal distribution of COVID19 vaccines between the Global North and the Global South (Rutschman, 2020). As scholars in psychology explained, the mechanism of "identity-protective cognition"2 might facilitate the spread of science misperception (Kahan, 2017), as demonstrated by our empirical evidence that conspiracy theories and blame went hand in hand with Sino-U.S. conflicts. Moreover, the pandemic is reshaping power structures and international systems between China and the United States, intensifying the Sino-U.S. competition and rivalry (Basu, 2020; Fiona et al., 2020). Narratives focusing on the politics of blame between China and the United States have escalated from political speeches to media coverage (Jaworsky \& Qiaona, 2020). Science communication has become politicized (Hart et al., 2020) and ideological (Wolfe, 2018). As science communication intertwines with political communication (Scheufele, 2014), it is vital to develop mutual understanding and meaningful dialogues between world powers to share responsibility for coping with pandemics and fighting misinformation.

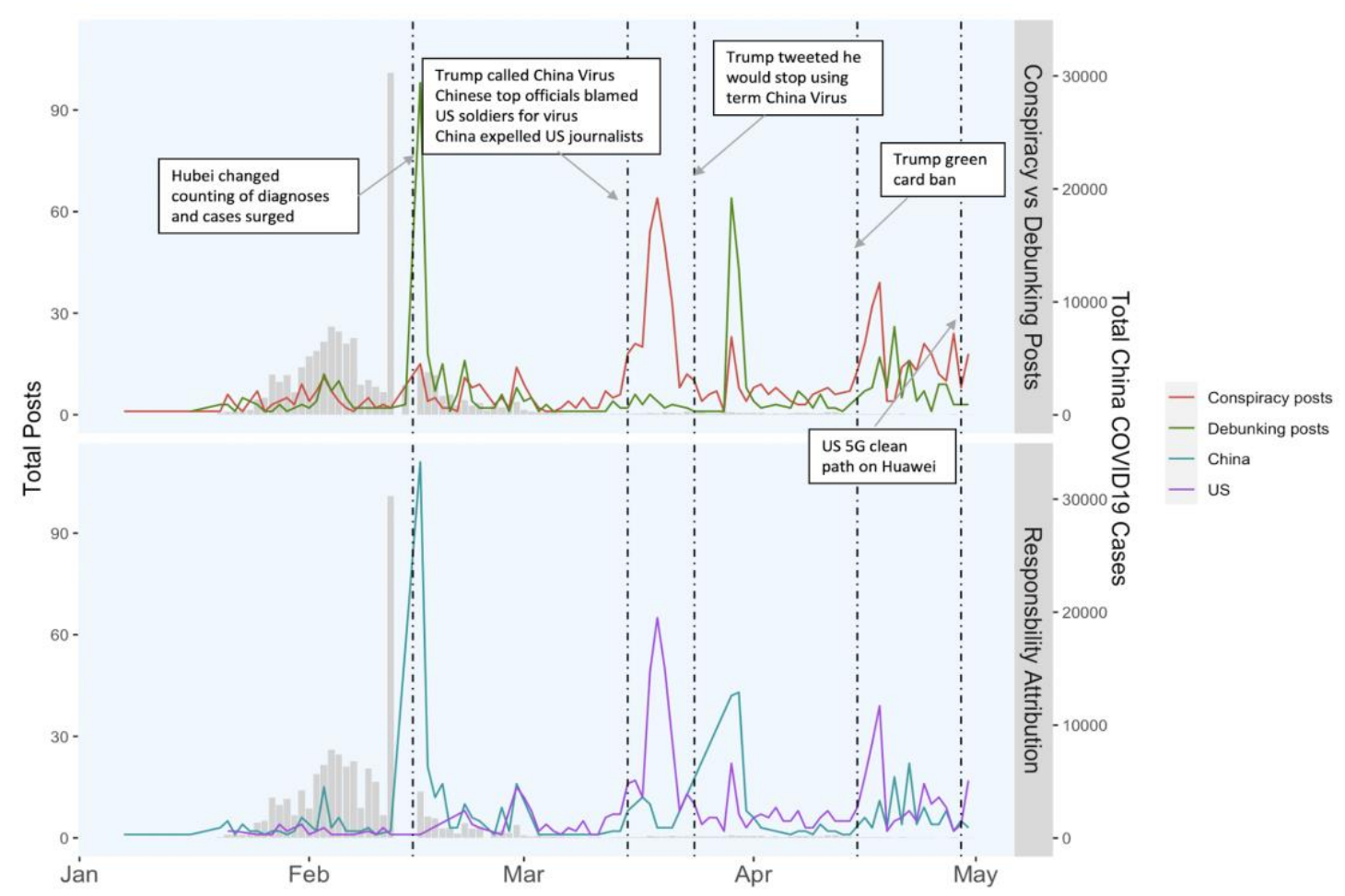

Figure 2. Evolution of conspiracy and debunking narratives and responsibility attribution.

\footnotetext{
${ }^{2}$ Identity-protective cognition refers to the phenomenon that individuals tend to adopt the beliefs that are held by members of their in-groups in order to protect the self-esteem and well-being of their identities.
} 
Finding 3: Men are more likely to propagate and debunk conspiracy posts than women; compared to the overall Weibo population, influencers and organizational users are overrepresented in debunking posts.

We found that the users who propagate conspiracy and who debunk conspiracy are similar in profile. Ordinary users, men, and users with followers between 100-1000 constitute the majority who post conspiracy as well as debunking posts. However, compared with the user profile of the overall Weibo population, a few notable trends emerge (Figure 3).

Among the users propagating conspiracy posts, organizational users are overrepresented $(5.19 \%)$ compared to the overall Weibo population (1.46\%), while influencers are slightly underrepresented (7.96\%) compared to the overall Weibo population (8.59\%). Among the users debunking conspiracy posts, organizational users are again overrepresented (8.51\%) in comparison with the overall Weibo population, while influencers are overrepresented (10.48\%) when compared to the overall Weibo population (8.59\%). Men are disproportionately more likely than women to post conspiracy $\left(\chi^{2}=108.52, p<0.01\right)$ and debunking posts $\left(\chi^{2}=52.57, p<0.01\right)$, compared to the gender composition in the overall Weibo population.
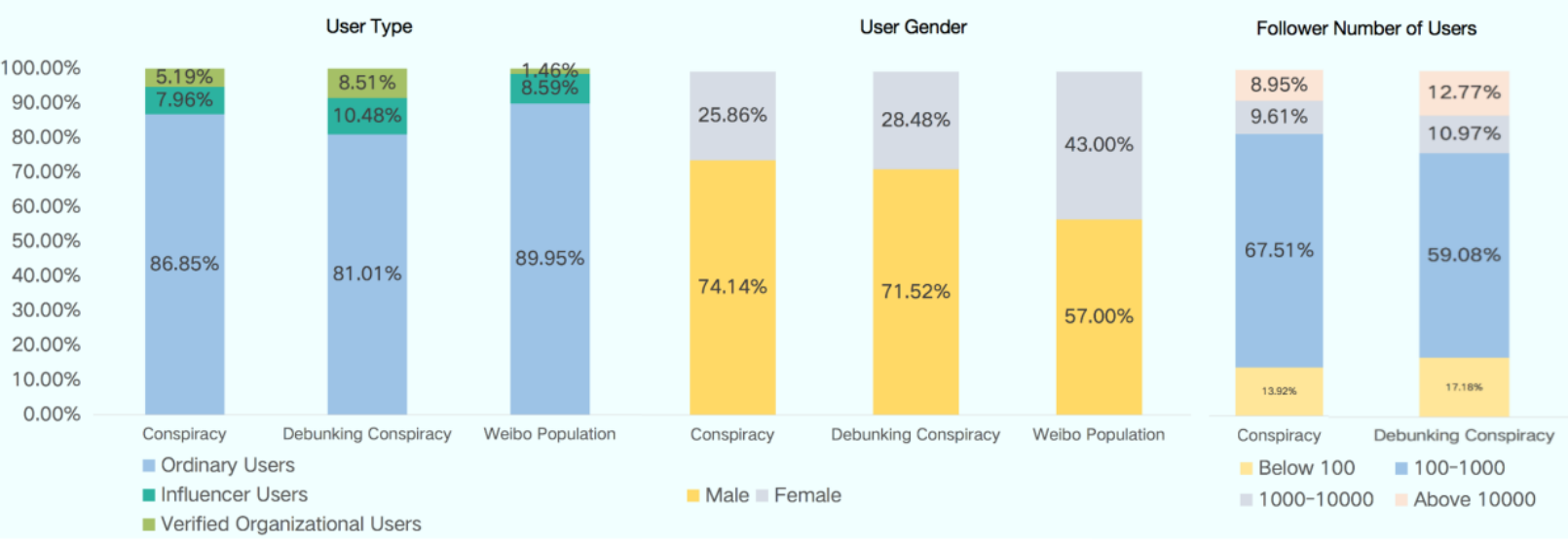

Figure 3. Conspiracy propagation and debunking behaviors by user type. Note: Data on "the number of followers" for the general Weibo population is not available.

Finding 4: Debunking posts have less user engagement than conspiracy posts; however, debunking can be more engaging when it comes from women and influencers and cites scientists.

In the baseline models with only user attributes and post type (conspiracy vs debunking posts), we found that, compared to conspiracy posts, debunking posts are associated with $10.06 \%(p=0.07)$ decrease in user participation (i.e., retweets, likes, comments), but $11.96 \%$ percent $(p<0.01$ ) increase in user mobilization (i.e., number of @ and hashtags to mobilize others). Although debunking posts are associated with lower participation, we found that the association is moderated by several factors. Within debunking posts, those posted by men received $36.87 \%$ less participation than those posted by women (Figure 4 , panel $A$, right bars), while the same engagement gap for conspiracy posts between men and women was $13.93 \%$ (Figure 4, panel A, left bars). Within debunking posts, a $10 \%$ increase in the number of followers is associated with $4.08 \%$ increase in participation (Figure 4, panel B, blue line), while for conspiracy posts, a $10 \%$ increase in the number of followers is associated with $3.05 \%$ increase in participation (Figure 4 , panel B, red line). For debunking posts, citing scientists as sources is associated with a higher level of mobilization $(20.93 \%, p=0.02)$ than those without citing sources (Figure 4, panel C, right bars). However, for conspiracy posts, citing scientists is associated with 3.92 percent lower mobilization than those 
without sources (Figure 4, panel C, left bars).
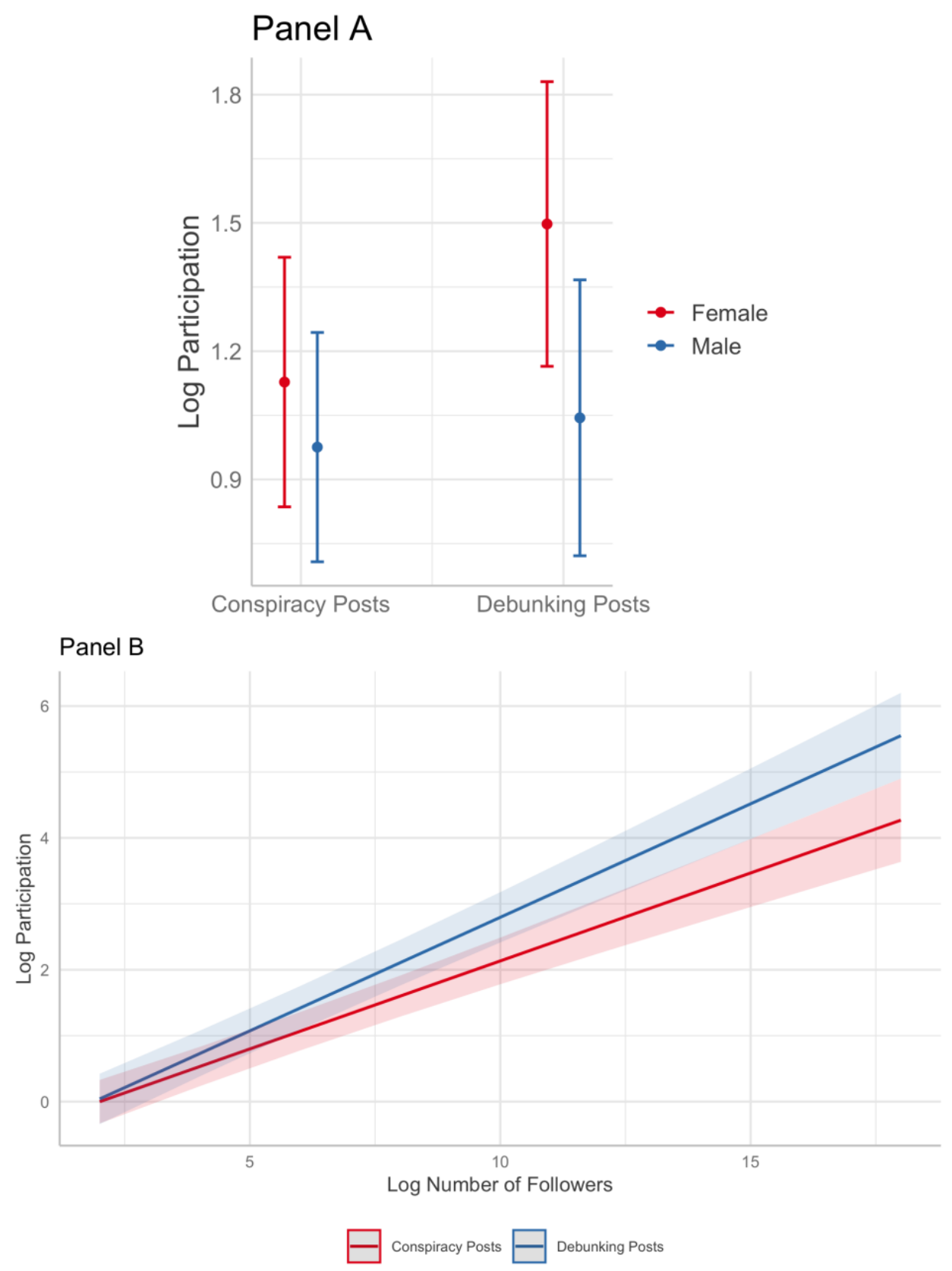


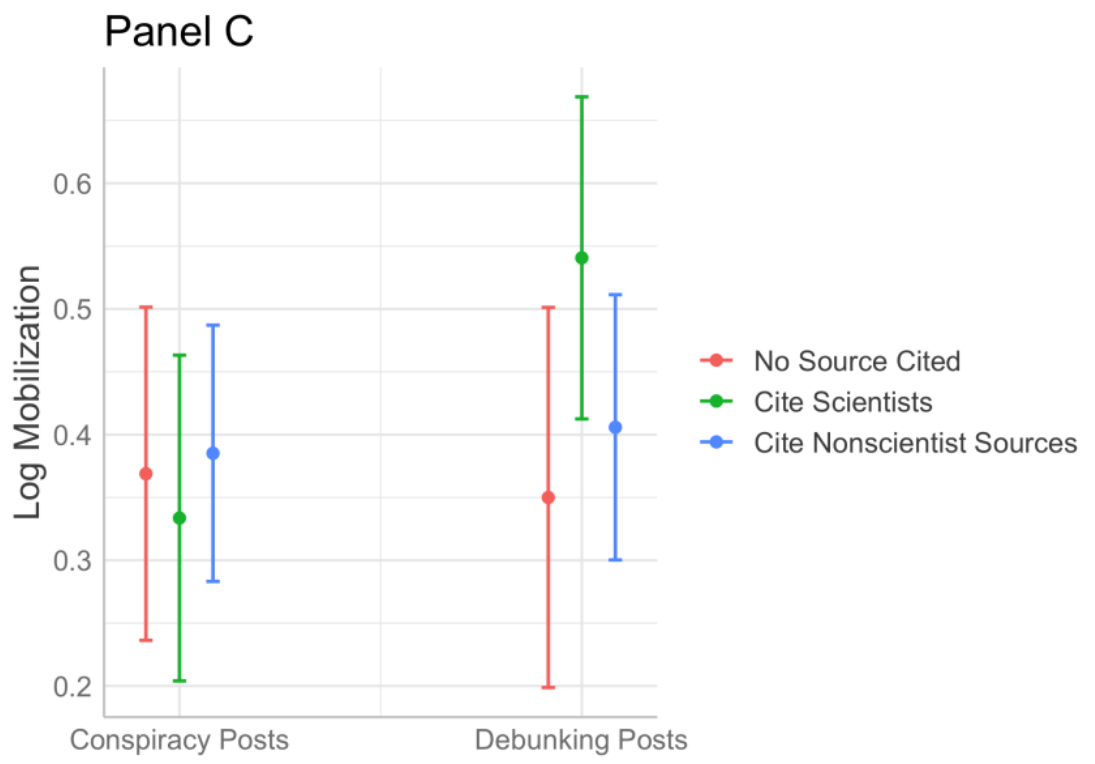

Figure 4. How user gender (A), number of followers (B) and source cited (C) moderate the associations between debunking posts and user participation and mobilization. A 95\% confidence interval for the marginal effect of the interaction terms on our dependent variables from the OLS regression are plotted. We took the log form for our dependent variables, participation and mobilization, accounting for their skewed distributions. We took the log form for our independent variable the number of

followers. For panel B, when log (number of followers) $=0$, the intercept of participation for conspiracy posts is -0.53 and the intercept of participation for debunking posts is -0.65. For details on the full regression results, please see Appendix $E$.

Our finding that debunking posts by women received more participation than those posted by men responds to a growing body of literature that examines gender differences in public engagement with social media content. For instance, Jia et al. (2018) showed that female online video uploaders were more popular than most male uploaders. The gender differences in how debunking messages were engaged with might be due to the language differences women and men use in persuasion (Carli, 1990; Falk \& Mills, 1996). Taking a close reading of the post content by women users that received many reposts, we found that these women used storytelling such as sharing about how COVID-19 has influenced their lives as oversea students. They also used more soft and tentative languages to discuss the origins of COVID-19 such as asking for people's mutual understanding about COVID-19 issues, suggesting that people not eat wild animals, rather than using hard propaganda language to attribute responsibility with assertion, which could backfire on audience acceptance of the message senders (Huang, 2018). In revealing the nuance of these moderators (such as gender), our study provides fruitful future research directions such as investigating how debunking strategies could be matched with specific senders to increase public engagement with science.

\section{Methods}

We performed content analyses and regression analyses to examine conspiracy narratives and user engagement. COVID-19 related social media posts were retrieved from Weibo (the Chinese Twitter with 560 million monthly active users at the end of 2019) (Sina Weibo, 2020). However, Weibo does not provide application programming interface (API) access to independent researchers and limits keyword search output to 50 pages (around 1000 posts). To bypass these limitations, we utilized a large Weibo user pool of 250 million users (with bots filtered out) (Hu et al., 2020; Shen et al., 2020), which accounts for 48.1\% of all monthly active Weibo users in 2019 (Sina Weibo, 2020). This user pool was originally built in 2018 and started from a list of 5 million active Weibo users collected in our previous studies unrelated to COVID- 
19 (Li et al., 2020; Zhang et al., 2020), along with a snowball sampling process. ${ }^{3}$

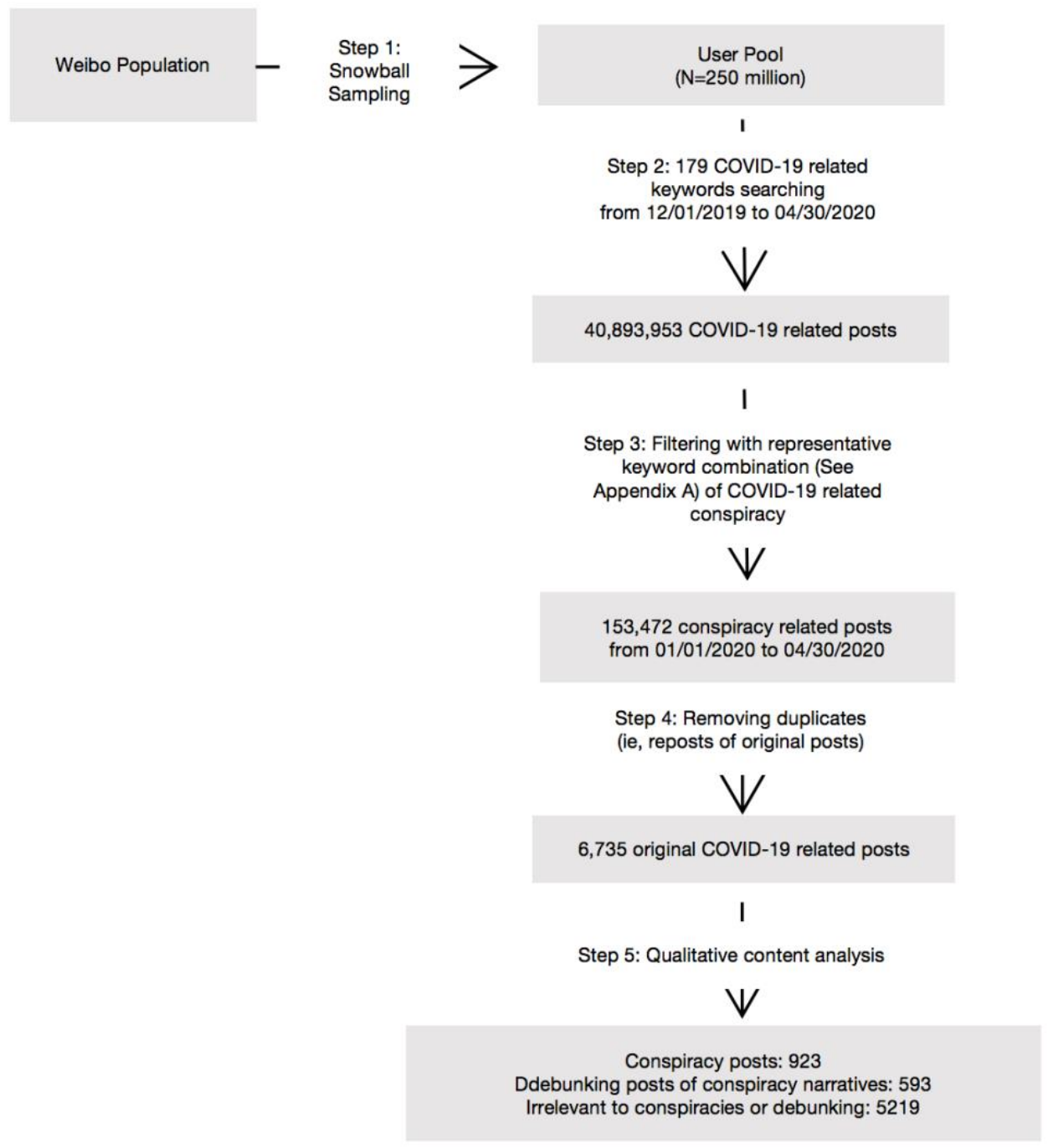

Figure 5. Weibo data collection and content analysis procedure.

From the user pool, we retrieved COVID-19 related posts using a comprehensive list of 179 keywords (for a complete list, see Hu et al., 2020). After removing duplicates, we obtained a main corpus of 40,893,953 COVID-19 related Weibo posts between December 1, 2019 (the date of the first known COVID-19 case) and April 30, 2020. Drawing from academic, government, and news resources, ${ }^{4}$ we found 35 COVID-19 conspiracy theories (e.g., "5G spreads virus", "China utilizes COVID-19 to paralyze the Western economy"). We summarized keyword combinations for each specific conspiracy narrative (see Appendix A) via close observation of their relevant posts on Weibo, along with several rounds of back-and-forth

\footnotetext{
${ }^{3}$ Using a snowball sampling method, we then retrieved the initial 5 million users' followers and followees (second degree users), the followers and followees of the second-degree users (third degree users), and so on until no new users appeared. This snowball process resulted in a pool of 250 million users (with bots filtered out) (Shen et al., 2020).

${ }^{4}$ We drew from 1) earlier research on COVID-19 conspiracies (Imhoff \& Lamberty, 2020; Leng et al., 2020), 2) Chinese factchecking websites (e.g., Tencent Jiaozhen), 3) news websites (e.g., BBC), and 4) government websites (e.g., Embassy of People's Republic of China in Germany).
} 
discussions. These keyword combinations were adopted to filter the COVID-19 corpus, yielding 153,472 posts from Jan 1, 2020 to April 30, 2020. We removed duplicate posts and reposts as practiced by other studies (González-Ibánez et al., 2011; Shen et al., 2020), because (a) we focus on the narrative of the person who initiated the conspiracy, and (b) we study the number of retweets of a post as a dependent variable. The final dataset contained 6,735 unique original Weibo posts ${ }^{5}$ about COVID-19 conspiracies dated from Jan 1, 2020 to April 30, 2020. These 6,735 original posts reached a large audience, generating 31,421 reposts, 260,355 likes, and 38,075 comments.

We developed a comprehensive coding scheme to manually annotate each post based on four dimensions: post types, origin types, responsibility attribution, and sources cited (see Appendix B for coding scheme). Post types focus on distinguishing posts that propagate conspiracies vs disapprove/refute conspiracies. Origin types concern the various theories on the origins of COVID-19 such as whether the source of COVID-19 is unknown or made by human actors. Responsibility attribution concerns the countries or entities who are pointed out in a post as responsible for causing the COVID-19 pandemic. Sources cited concerns the type of sources cited in a post such as from government, scientists, media, and so on. Six native Chinese speakers were trained and coded the posts independently, and satisfactory intercoder reliability was achieved (see Appendix C).

To examine the relationship between post type, origin types, responsibility attribution, and sources cited, we first calculated the frequency of each category (see Appendix C). To examine the association between post type and user engagement, two regression models were conducted. In the models, our two dependent variables are post participation including like number, repost number, and comment number and post mobilization including number of @s and hashtags in a post. In our baseline model, our independent variables include post type (conspiracy or debunking), user gender, user type, geolocation (Hubei or outside Hubei), emotional factors (i.e., emotion score, emotion polarity, and emotion types which were calculated drawing upon Zhang et al., 2017 and Zhao et al., 2016), and length of a post (see Appendix D). In the full model, we added hand-coded variables such as origin types, responsibility attribution, and source cited in addition to the baseline variables. To examine what debunking strategies might be associated with variation in user engagement, our full model also included the interaction of debunking and source cited, debunking and origin types, and debunking and user attributes (see Appendix E).

\section{Limitations and robustness}

This study has several limitations. First, Weibo posts were collected retrospectively on May 16, 2020 and thus our dataset does not contain deleted or censored posts. However, this potential exclusion should not interfere with our conclusions as a previous study found that only $0.17 \%$ of all Weibo posts on COVID-19 were censored, and these censored posts were generally about the government's missteps in COVID-19 response, not about COVID-19 origination (Fu \& Zhu, 2020). Second, our study is exploratory in nature. Findings on associations between debunking strategies and user engagement and patterns of conspiracy and responsibility attribution evolution with Sino-U.S. conflicts should not be interpreted as causal. Finally, as our findings demonstrate, conspiracies prevalent on Chinese social media might differ significantly from those of other countries or other media systems. It will be fruitful for future research to examine major conspiracy theories emerged during COVID-19 in other countries to compare how conspiracy narratives might differ among various media systems. It will also be interesting to examine responsibility attribution by U.S. users on Twitter. In fact, some research has shown that over $78 \%$ of Americans blamed China for its role in spreading COVID-19 (Silver et al., 2020).

\footnotetext{
${ }^{5}$ Original posts are posts that start threads, not reposts or comments.
} 


\section{Bibliography}

Ahmed, W., Vidal-Alaball, J., Downing, J., \& Seguí, F. L. (2020). COVID-19 and the 5G conspiracy theory: Social network analysis of Twitter data. Journal of Medical Internet Research, 22(5), e19458. https://doi.org/10.2196/19458

Basu, T. (2020). Sino-US Disorder: Pandemic, power and policy perspectives in Indo-Pacific. Journal of Asian Economic Integration, 2, 159-179. https://doi.org/10.1177/2631684620940448

Carli, L. L. (1990). Gender, language, and influence. Journal of Personality and Social Psychology, 59(5), 941-951. https://doi.org/10.1037/0022-3514.59.5.941

Del Vicario, M., Bessi, A., Zollo, F., Petroni, F., Scala, A., Caldarelli, G., Stanley, H. E., \& Quattrociocchi, W. (2016). The spreading of misinformation online. Proceedings of the National Academy of Sciences, 113(3), 554-559. https://doi.org/10.1073/pnas.1517441113

Ding, H., \& Zhang, J. (2010). Social media and participatory risk communication during the H1N1 flu epidemic: A comparative study of the United States and China. China Media Research, 6(4), 8091.http://chatrlab.ucdavis.edu/uploads/8/4/7/8/84783462/social media and participatory ris k communication during the h1n1 flu epidemic - a comparative study.pdf

Falk, E., \& Mills, J. (1996). Why sexist language affects persuasion: The role of homophily, intended audience, and offense. Women and Language, 19(2), 36-44. https://www.questia.com/library/journal/1G1-19265426

Freeman, D., Waite, F., Rosebrock, L., Petit, A., Causier, C., East, A., Jenner, L., Teale, A.-L., Carr, L., Mulhall, S., Boled, E., \& Lambe, S. (2020). Coronavirus conspiracy beliefs, mistrust, and compliance with government guidelines in England. Psychological Medicine, 1-13. https://doi.org/10.1017/S0033291720001890

Fu, K. W., \& Zhu, Y. (2020). Did the world overlook the media's early warning of COVID-19? Journal of Risk Research, 1-5. https://doi.org/10.1080/13669877.2020.1756380

Georgiou, N., Delfabbro, P., \& Balzan, R. (2020). COVID-19-related conspiracy beliefs and their relationship with perceived stress and pre-existing conspiracy beliefs. Personality and Individual Differences, 166, 110201. https://doi.org/10.1016/j.paid.2020.110201

González-Ibánez, R., Muresan, S., \& Wacholder, N. (2011, June 19). Identifying sarcasm in Twitter: A closer look. Proceedings of the 49th Annual Meeting of the Association for Computational Linguistics: Human Language Technologies (pp. 581-586). https://dl.acm.org/doi/10.5555/2002736.2002850

Goodman, J. \& Carmichael, F. (2020, June 27). Coronavirus: $5 \mathrm{G}$ and microchip conspiracies around the world. BBC News. https://www.bbc.com/news/53191523

Hart, P. S., Chinn, S., \& Soroka, S. (2020). Politicization and polarization in Covid-19 news coverage. Science Communication, 42(5), 679-697. https://doi.org/10.1177/1075547020950735

Hill, F., Madan, T., Sloat A., Solis, M., \& Stelzenmüller, C. (2020, July 1). Balancing act: Major powers and the global responses to US-China great power competition. Foreign Policy at Brookings. https://www.brookings.edu/wpcontent/uploads/2020/07/FP 20200701 us china competition.pdf

Huang, H. (2018). The pathology of hard propaganda. The Journal of Politics, 80(3), 1034-1038. https://dl.acm.org/doi/abs/10.1086/696863

Hu, Y., Huang, H., Chen, A., \& Mao, X. L. (2020). Weibo-COV: A large-scale COVID-19 tweets dataset from Weibo. https://arxiv.org/abs/2005.09174 
Imhoff, R., \& Lamberty, P. (2020). A bioweapon or a hoax? The link between distinct conspiracy beliefs about the Coronavirus disease (COVID-19) outbreak and pandemic behavior. Social Psychological and Personality Science, 11(8), 1110-1118. https://doi.org/10.1177/1948550620934692

Jamieson, K. H., \& Albarracin, D. (2020). The relation between media consumption and misinformation at the outset of the SARS-CoV-2 Pandemic in the US. Harvard Kennedy School (HKS) Misinformation Review, 1(2), 1-22. https://doi.org/10.37016/mr-2020-012

Jaworsky, B. N., \& Qiaoan, R. (2020). The politics of blaming: The narrative battle between China and the US over COVID-19. Journal of Chinese Political Science, 1-21. https://doi.org/10.1007/s11366$\underline{020-09690-8}$

Jia, A. L., Shen, S., Li, D., \& Chen, S. (2018). Predicting the implicit and the explicit video popularity in a user generated content site with enhanced social features. Computer Networks, 140, 112-125. https://doi.org/10.1016/i.comnet.2018.05.004

Jovančević, A., \& Milićević, N. (2020). Optimism-pessimism, conspiracy theories and general trust as factors contributing to COVID-19 related behavior - A cross-cultural study. Personality and Individual Differences, 167, 110216. https://doi.org/10.1016/j.paid.2020.110216

Kahan, Dan M. (2017, October 2). Misinformation and identity-protective cognition. Yale Law \& Economics Research Paper No. 587. https://ssrn.com/abstract=3046603

Leng, Y., Zhai, Y., Sun, S., Wu, Y., Selzer, J., Strover, S., Fensel, J., Pentland, A., \& Ding, Y. (2020). Misinformation during the COVID-19 outbreak in China: Cultural, social, and political entanglements [Manuscript submitted for publication].

Li, P., Cho, H., Qin, Y., \& Chen, A. (2020). \#MeToo as a connective movement: Examining the frames adopted in the anti-sexual harassment movement in China. Social Science Computer Review. https://doi.org/10.1177/0894439320956790

Mitchell, A., Jurkowitz, M., Oliphant, J. B., Shearer, E. (2020, June 29). Three months in, many Americans see exaggeration, conspiracy theories and partisanship in COVID-19 news. Pew Research Center: Journalism \& Media. https://www.journalism.org/2020/06/29/three-months-in-manyamericans-see-exaggeration-conspiracy-theories-and-partisanship-in-covid-19-news/

Roozenbeek, J., \& Van der Linden, S. (2019). The fake news game: Actively inoculating against the risk of misinformation. Journal of Risk Research, 22(5), 570-580. https://doi.org/10.1080/13669877.2018.1443491

Rubin, V. L. (2017). Deception detection and rumor debunking for social media. In L. Sloan \& A. QuanHaase (Eds.), The SAGE Handbook of Social Media Research Methods (pp. 342-364). Sage Publishing. https://uk.sagepub.com/en-gb/eur/the-sage-handbook-of-social-mediaresearchmethods/book245370

Rutschman, A. S. (2020). The COVID-19 vaccine race: Intellectual property, collaboration(s), nationalism, and misinformation. Washington University Journal of Law and Policy, 64. https://ssrn.com/abstract=3656929

Scheufele, D. A. (2014). Science communication as political communication. Proceedings of the National Academy of Sciences, 111(Supplement 4), 13585-13592. https://doi.org/10.1073/pnas.1317516111

Shen, C., Chen, A., Luo, C., Zhang, J., Feng, B., \& Liao, W. (2020). Using reports of symptoms and diagnoses on social media to predict COVID-19 case counts in mainland China: Observational infoveillance study. Journal of Medical Internet Research, 22(5), e19421. https://doi.org/10.2196/19421

Shin, J., \& Thorson, K. (2017). Partisan selective sharing: The biased diffusion of fact-checking messages on social media. Journal of Communication, 67(2), 233-255. https://doi.org/10.1111/jcom.12284 
Silver, L., Devlin, K., Huang, C. (2020, July 30). Americans fault China for its role in the spread of COVID19. Pew Research Center: Global Attitudes and Trends. https://www.pewresearch.org/global/2020/07/30/americans-fault-china-for-its-role-in-thespread-of-covid-19/

Sina Weibo. (2020, April 19). Weibo reports first quarter 2020 unaudited financial results. Sina Corporation. http://ir.weibo.com/news-releases/news-release-details/weibo-reports-firstquarter-2020-unaudited-financialresults\#: :text=For\%20the\%20first\%20quarter\%20of,the\%20same\%20period\%20last\%20year

Sunstein, C. R., \& Vermeule, A. (2009). Conspiracy theories: Causes and cures. Journal of Political Philosophy, 17(2), 202-227. https://doi.org/10.1111/j.1467-9760.2008.00325.x

Swire-Thompson, B., \& Lazer, D. (2020). Public health and online misinformation: Challenges and recommendations. Annual Review of Public Health, 41, 433-451. https://doi.org/10.1146/annurev-publhealth-040119-094127

Vosoughi, S., Roy, D., \& Aral, S. (2018). The spread of true and false news online. Science, 359(6380), 1146-1151. https://doi.org/10.1126/science.aap9559

Wolfe, Audra J. (2018). Freedom's laboratory: The Cold War struggle for the soul of science. Johns Hopkins University Press.

Zhang, L., Xu, L., \& Zhang, W. (2017). Social media as amplification station: Factors that influence the speed of online public response to health emergencies. Asian Journal of Communication, 27(3), 322-338. https://doi.org/10.1080/01292986.2017.1290124

Zhang, X., Nekmat, E., \& Chen, A. (2020). Crisis collective memory making on social media: A case study of three Chinese crises on Weibo. Public Relations Review, 46(4), 101960. https://doi.org/10.1016/i.pubrev.2020.101960

Zhao, N., Jiao, D., Bai, S., \& Zhu, T. (2016). Evaluating the validity of simplified Chinese version of LIWC in detecting psychological expressions in short texts on social network services. PLoS One, 11(6), e0157947. https://doi.org/10.1371/journal.pone.0157947 


\section{Authorship}

All authors contributed equally to this work.

\section{Funding}

Anfan Chen's research was supported by the 25th department funding of USTC (Grant code: DA2110251001), 2019 New Humanities Funding of USTC (Grant code: YD2110002015), the Shanghai Social Science Funding Research on Scientific Discourse Construction and Public Opinion Guidance Mechanism of Public Emergency (Grant code: 2020EXW005), and the National Social Science Foundation Youth Project Research on automatic classification of network ideology and comprehensive management of man-machine based on artificial intelligence (Grant code: 20CXW026).

\section{Competing interests}

The authors declared no potential conflicts of interest with respect to the research, authorship, and/or publication of this article.

\section{Ethics}

The data for the project were obtained from publicly available sources and thus were exempt from IRB review.

\section{Copyright}

This is an open access article distributed under the terms of the Creative Commons Attribution License, which permits unrestricted use, distribution, and reproduction in any medium, provided that the original author and source are properly credited.

\section{Data availability}

All materials needed to replicate this study are available via the Harvard Dataverse: https://doi.org/10.7910/DVN/WHGM1D 


\section{Appendix A: COVID-19 conspiracy theories and their representative keyword combination}

\begin{tabular}{|c|c|c|}
\hline Conspiracy Narratives & Representative Keywords & Translation \\
\hline $\begin{array}{l}\text { 震惊哈佛大学教授 : 新型冠状 } \\
\text { 病毒诞生于人为基因改造 }\end{array}$ & $\begin{array}{l}\text { 新冠 AND人为/新冠AND基因改 } \\
\text { 造 }\end{array}$ & $\begin{array}{lcr}\text { COVID-19 } & \text { AND } & \text { Human } \\
\text { Synthesized/COVID-19 AND Gene Editing }\end{array}$ \\
\hline $\begin{array}{l}\text { 武汉病毒所女研究生黄燕玲是 } \\
\text { 新冠肺炎零号病人 }\end{array}$ & $\begin{array}{l}\text { 武汉病毒所AND零号病人/黄燕 } \\
\text { 玲AND零号病人/女研究生 AND } \\
\text { 零号病人 }\end{array}$ & $\begin{array}{l}\text { Wuhan Institute of Virology AND Index } \\
\text { Case/Huang Yanling AND Index } \\
\text { Case/Female postgraduate AND Index } \\
\text { Case }\end{array}$ \\
\hline $\begin{array}{l}\text { 新型冠状病毒是由实验室制造 } \\
\text { 的生物武器 }\end{array}$ & 新型冠状AND实验室AND武器 & COVID-19 AND Lab AND Weapon \\
\hline $\begin{array}{l}\text { 俄美国疾控中心确认新冠病毒 } \\
\text { 源头是美国 }\end{array}$ & 病毒源头AND美国 & Virus Source AND USA \\
\hline $\begin{array}{l}\text { 台湾专家 : 根据一篇论文可以 } \\
\text { 得出新冠病毒源头是美国 }\end{array}$ & 病毒源头AND美国 & Virus Source AND USA \\
\hline $\begin{array}{l}\text { 俄罗斯科学家验证新冠病毒为 } \\
\text { 人工合成病毒 }\end{array}$ & 新冠病毒AND人工合成 & COVID-19 AND Human Synthesized \\
\hline $\begin{array}{l}\text { 美国的电子烟肺炎是新型冠状 } \\
\text { 病毒导致 }\end{array}$ & 电子烟肺炎AND新型冠状 & E-cigarette pneumonia AND COVID-19 \\
\hline $\begin{array}{l}\text { 美国疾控中心确认新冠病毒源 } \\
\text { 头是美国 }\end{array}$ & 病毒源头AND美国 & Virus Source AND USA \\
\hline 华裔教授因新冠研究被灭口? & $\begin{array}{l}\text { 华裔教授AND新冠研究AND灭 } \\
\text { 口 }\end{array}$ & $\begin{array}{l}\text { Chinese professor AND killed AND } \\
\text { research on COVID-19 }\end{array}$ \\
\hline $\begin{array}{l}\text { 中国的新型冠状疫情是美国发 } \\
\text { 动的秘密武器，有助于美国制 } \\
\text { 造业复苏......美国病毒战的目 } \\
\text { 的，不但是贸易战，更是毁我 } \\
\text { 长城灭我中华 }\end{array}$ & $\begin{array}{l}\text { 新型冠状AND秘密武器/新型冠 } \\
\text { 状AND病毒战 }\end{array}$ & $\begin{array}{l}\text { COVID-19 AND secret weapon/COVID-19 } \\
\text { AND war }\end{array}$ \\
\hline $\begin{array}{l}\text { 2019新型冠状病毒棘突蛋白中 } \\
\text { 含有独特的插入序列，并与艾 } \\
\text { 滋病毒的HIV-1 gp120和Gag蛋白 } \\
\text { 有奇特的相似性 }\end{array}$ & 新型冠状病毒 AND gp120 or Gag & $\begin{array}{l}\text { COVID-19 AND gp120/COVID-19 AND } \\
\text { Gap }\end{array}$ \\
\hline $\begin{array}{l}\text { 中国早在2019年11月中旬就获 } \\
\text { 悉疫情爆发，将有关信息隐瞒 } \\
45 \text { 天 }\end{array}$ & 中国AND信息AND隐瞒 & China AND COVID-19 AND Hide \\
\hline
\end{tabular}




\begin{tabular}{|c|c|c|}
\hline $\begin{array}{l}\text { 中国长时间隐瞒新冠疫情爆发 } \\
\text { 真相，才导致全球疫情爆发 }\end{array}$ & 中国AND隐瞒AND疫情AND爆发 & $\begin{array}{l}\text { China AND hide AND Epidemic AND } \\
\text { Outbreak }\end{array}$ \\
\hline $\begin{array}{l}\text { 台湾早在2019年12月31日就向 } \\
\text { 世卫组织发出关于新冠肺炎人 } \\
\text { 传人的警告，但未获得重视 }\end{array}$ & 台湾AND人传人AND警告 & $\begin{array}{l}\text { Taiwan AND Person-to-person AND } \\
\text { Warning }\end{array}$ \\
\hline $\begin{array}{l}\text { 新型冠状病毒早在2018年就被 } \\
\text { 发现 }\end{array}$ & $\begin{array}{l}\text { 新型冠状病毒AND 2018AND发 } \\
\text { 现/新冠状AND 2018/新肺炎 } \\
\text { AND2018 }\end{array}$ & $\begin{array}{l}\text { COVID-19 AND } 2018 \\
\text { Discover/COVID-19 } 2018\end{array}$ \\
\hline $\begin{array}{l}\text { 中国长时间隐瞒新冠疫情爆发 } \\
\text { 真相，才导致全球疫情爆发 }\end{array}$ & 隐瞒AND疫情AND爆发 & Hide AND Epidemic AND Outbreak \\
\hline $\begin{array}{l}\text { 中国为了隐瞒疫情爆发，逮捕 } \\
\text { 了最早向世人示警的医生 }\end{array}$ & 隐瞒疫情AND逮捕AND医生 & Epidemic Hide AND Arrest AND Doctor \\
\hline $\begin{array}{l}\text { 中国隐瞒并美化了新冠肺炎确 } \\
\text { 诊和死亡人数 } \\
\text { 中国操纵世界卫生组织，以确 } \\
\text { 保其不会批评中国 }\end{array}$ & $\begin{array}{l}\text { 中国AND隐瞒AND确诊人数or 死 } \\
\text { 亡人数 } \\
\text { 中国AND 操纵AND世界卫生组织 }\end{array}$ & $\begin{array}{l}\text { Hide AND Confirmed Cases OR death } \\
\text { Cases } \\
\text { China AND Manipulate AND WHO }\end{array}$ \\
\hline $\begin{array}{l}\text { 中国阻止台湾加入世卫组织， } \\
\text { 危害台湾人的健康 }\end{array}$ & $\begin{array}{l}\text { 中国AND阻止AND台湾AND 加入 } \\
\text { 世卫组织 }\end{array}$ & $\begin{array}{l}\text { China AND Prevent AND Taiwan AND join } \\
\text { WHO }\end{array}$ \\
\hline $\begin{array}{l}\text { 中国帮助其他国家抗疫只是为 } \\
\text { 了扩大地缘政治影响力 }\end{array}$ & $\begin{array}{l}\text { 中国AND抗疫AND扩大地缘政治 } \\
\text { 影响力 }\end{array}$ & $\begin{array}{l}\text { China AND Fights the epidemic AND } \\
\text { Expands geopolitical influence }\end{array}$ \\
\hline $\begin{array}{l}\text { 中国利用新冠病毒使西方经济 } \\
\text { 㿈疾 }\end{array}$ & $\begin{array}{l}\text { 中国AND新冠病毒AND西方经济 } \\
\text { 瘫疾 }\end{array}$ & $\begin{array}{l}\text { China AND COVID-19 AND Paralyze } \\
\text { Western Economy }\end{array}$ \\
\hline $\begin{array}{l}\text { 华大基因出卖中国人的基因信 } \\
\text { 息，美国人针对中国人的基因 } \\
\text { 投放病毒 }\end{array}$ & $\begin{array}{l}\text { 新冠状AND基因武器OR病毒是 } \\
\text { 美国人工合成的OR“可精准攻击 } \\
\text { 华人 }\end{array}$ & $\begin{array}{l}\text { COVID-19 AND Gene Weapon/ Human } \\
\text { synthesized Virus AND USA/Accurately } \\
\text { attack Chinese }\end{array}$ \\
\hline $\begin{array}{l}\text { 意大利病毒 ; 中国疫情暴发前 } \\
\text { 病毒或已在意大利传播了 }\end{array}$ & $\begin{array}{l}\text { 意大利病毒/ 中国疫情暴发前病 } \\
\text { 毒或已在意大利传播了 }\end{array}$ & $\begin{array}{l}\text { Italy Virus/Virus spread in Italy before } \\
\text { outbreak in China }\end{array}$ \\
\hline 5G传播病至 & 5G AND 传播病毒 & 5G Spread Virus \\
\hline 拉脱维 & 拉脱维亚AND发明病毒 & Latvia invented the virus \\
\hline
\end{tabular}




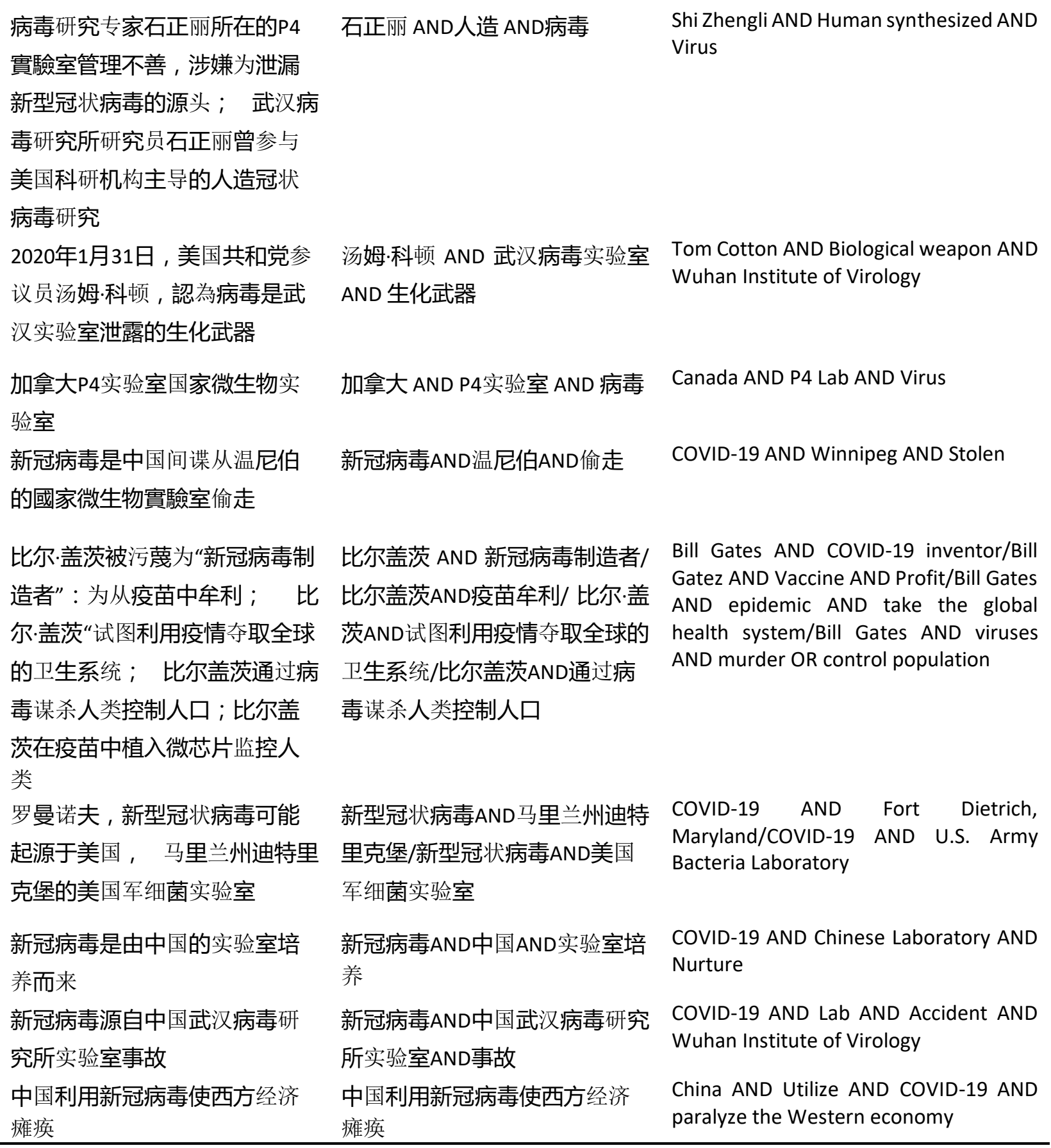




\section{Appendix B: Coding scheme with definitions and operationalizations}

The table below introduced the definition and attributes for our four content analysis variables: post types, origin types, responsibility attribution, and sources cited. Post types include: 1) conspiracy posts, 2) debunking posts that correct conspiracy narratives, and 3) irrelevant to conspiracies or debunking: other posts which contain conspiracy keywords but are not specifically about COVID-19 origin (e.g., conspiracy or debunking posts about local government corruption). Origin types concern the various theories on the origins of COVID-19, including: (1) COVID-19 came from nature or some unknown origin (nature/unknown origin); (2) COVID-19 was entirely developed by humans (human synthesis), (3) COVID19 was the result of modifying the genes of one or more natural organisms (lab-edited), (4) COVID-19 was developed as a biological weapon (bioweapon), (5) COVID-19 is caused by 5G (5G), (6) Smoking ecigarettes caused COVID-19 (e-cigarette), (7) Genetically modified crops caused COVID-19 (GMO), and (8) Others. Responsibility attribution concerns the country or entities who are responsible for causing the COVID-19 pandemic as pointed out in a post, including: (1) China, (2) The United States, (3) Japan, (4) Serbia, (5) other European countries, (6) Bill Gates, (7) other countries (outside of the above-mentioned countries), and (8) no clear responsibility attribution. Sources cited include: (1) government sources (documents, officials, organizations) (2) scientific scholars, (3) celebrities, (4) ordinary people, (5) foreign media, (6) Chinese media, (7) industry/companies, (8) non-governmental organizations, (9) others (outside of the above categories), and (10) no sources. For origin type, responsibility attribution and sources cited, coders were allowed to select multiple categories simultaneously.

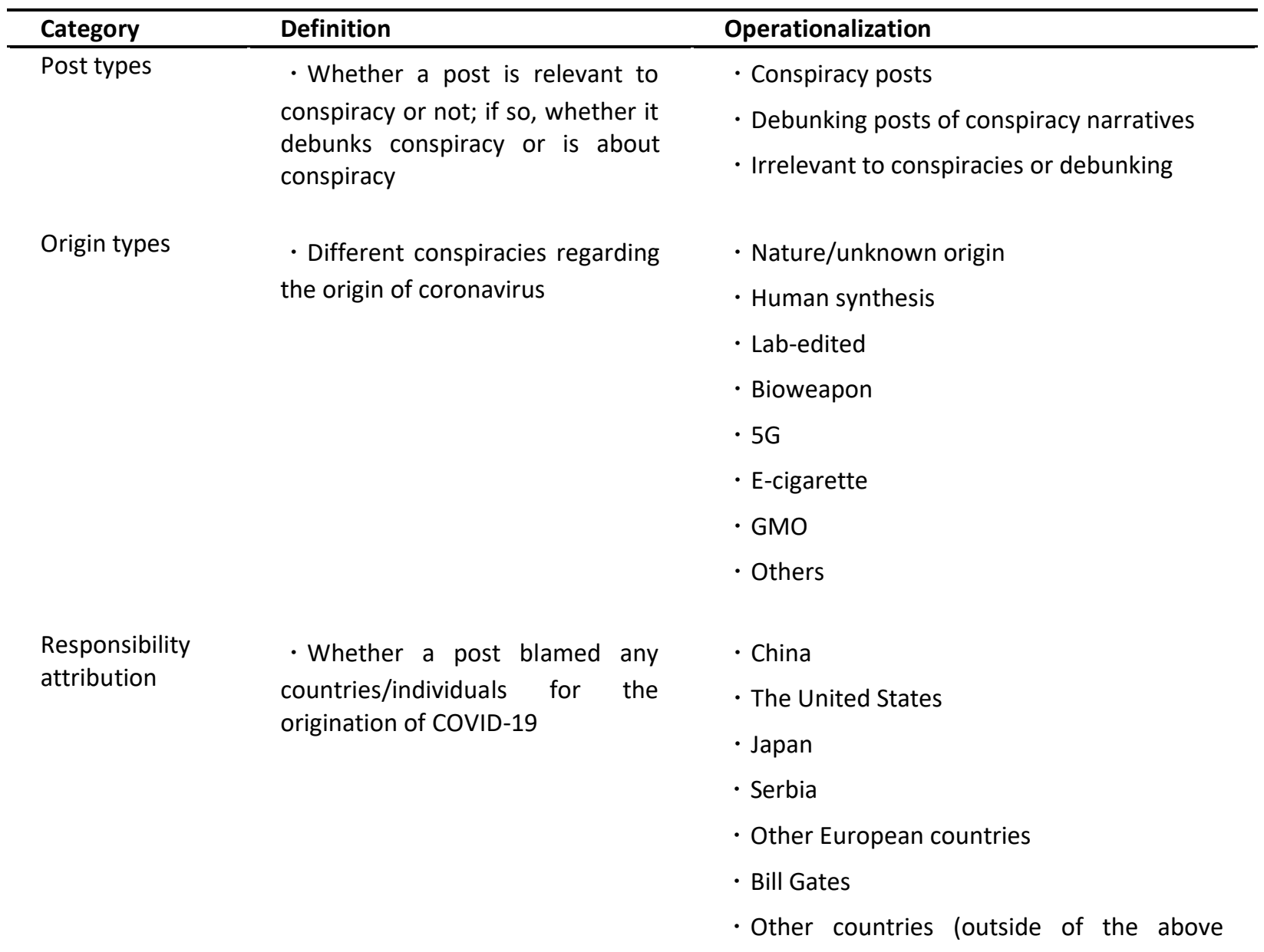


countries)

- No clear responsibility attribution

Sources cited

- Source is a person, thing, or place from which information comes, arises, or is quoted or referenced in a post

- Government sources (documents, officials, organizations): Chinese government, the U.S. government, and the governments of other countries

- Scientific scholars

- Celebrities

- Ordinary people

- Foreign media

- Chinese media

- Industry/companies

- Non-governmental organizations

- Others (outside of the above categories)

- No sources 


\section{Appendix C: Descriptive table for each hand-coded conspiracy related variables}

The coding scheme was iteratively developed and pilot-tested with 100 randomly sampled Weibo posts from the final dataset. Six Chinese native speakers were trained and coded the posts independently. Intercoder-reliability was satisfactory, with Krippendorff's alpha for post type, origin types, responsibility attribution, and source cited at $0.834,0.786,0.804,0.826$, respectively. The table below provides the descriptive results of coding of each variable.

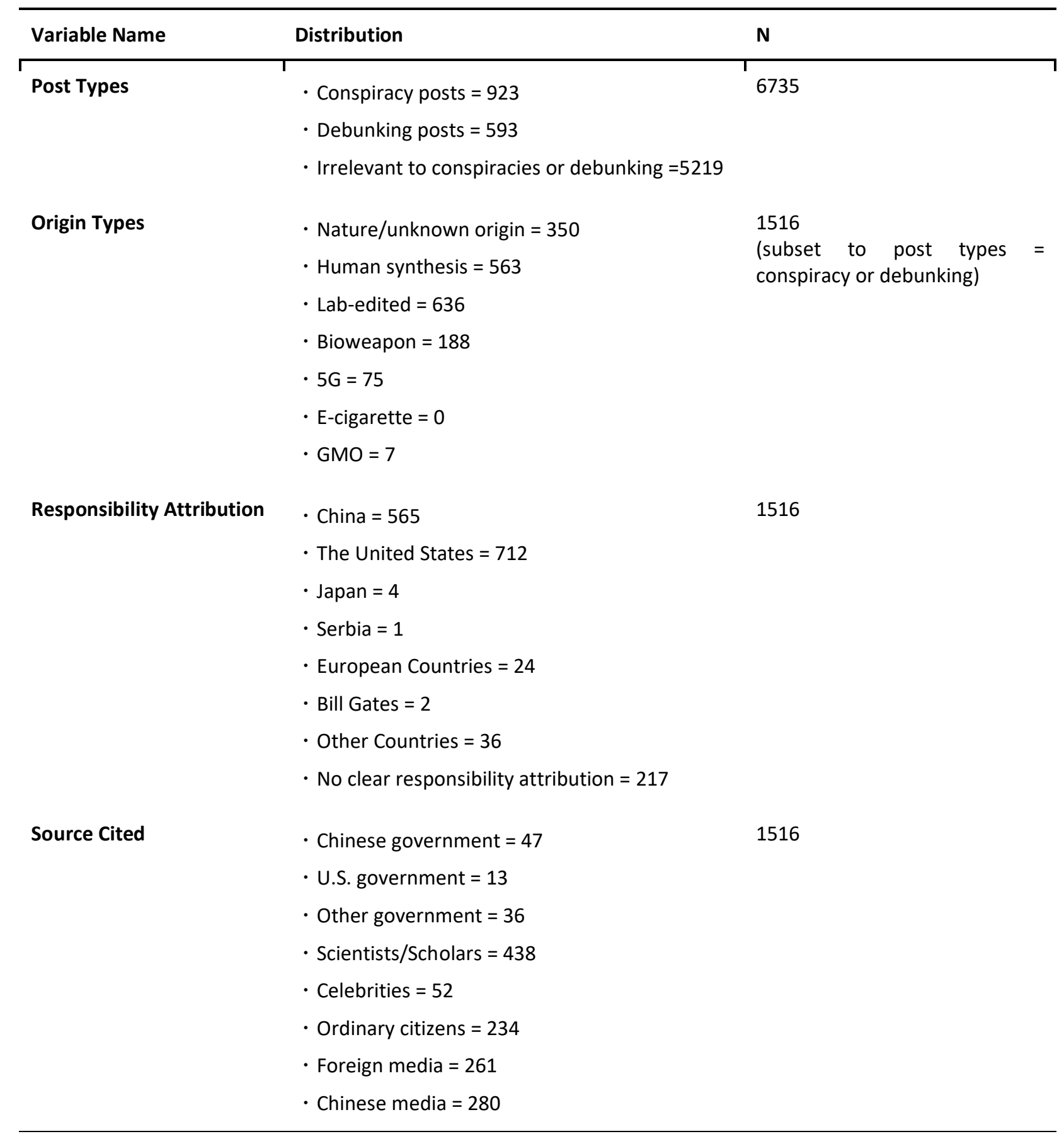


- Corporations $=2$

- $\mathrm{NGO}=5$

- Others $=108$

- No source is cited in a post $=268$ 


\section{Appendix D: Regression table output for the baseline model described in Finding 4}

Associations of Debunking to User Participation and Mobilization - Baseline Model

\begin{tabular}{|c|c|c|}
\hline & $\begin{array}{c}\text { Participation } \\
\text { (1) }\end{array}$ & $\begin{array}{c}\text { Mobilization } \\
\text { (2) }\end{array}$ \\
\hline Debunking posts & $\begin{array}{c}-0.106^{*} \\
(0.059)\end{array}$ & $\begin{array}{c}0.113^{* * *} \\
(0.026)\end{array}$ \\
\hline Male & $\begin{array}{c}-0.276^{* * *} \\
(0.063)\end{array}$ & $\begin{array}{c}-0.062^{* *} \\
(0.029)\end{array}$ \\
\hline Influencer & $\begin{array}{l}-0.063 \\
(0.122)\end{array}$ & $\begin{array}{c}0.187^{* * *} \\
(0.055)\end{array}$ \\
\hline Organization & $\begin{array}{c}-0.674^{* * *} \\
(0.138)\end{array}$ & $\begin{array}{c}0.180^{* * *} \\
(0.062)\end{array}$ \\
\hline Number of followers & $\begin{array}{c}0.303^{* * *} \\
(0.019)\end{array}$ & $\begin{array}{c}0.004 \\
(0.008)\end{array}$ \\
\hline Hubei & $\begin{array}{l}-0.055 \\
(0.140)\end{array}$ & $\begin{array}{c}0.018 \\
(0.063)\end{array}$ \\
\hline User total posts & $\begin{array}{l}-0.00000 \\
(0.00000)\end{array}$ & $\begin{array}{l}0.00000^{* *} \\
(0.00000)\end{array}$ \\
\hline Emotion score & $\begin{array}{c}-0.005^{*} \\
(0.003)\end{array}$ & $\begin{array}{c}-0.004^{* * *} \\
(0.001)\end{array}$ \\
\hline Emotion polarity & $\begin{array}{l}-0.090 \\
(0.082)\end{array}$ & $\begin{array}{l}0.065^{*} \\
(0.037)\end{array}$ \\
\hline Anger & $\begin{array}{c}0.009 \\
(0.026)\end{array}$ & $\begin{array}{c}-0.027^{* *} \\
(0.012)\end{array}$ \\
\hline Anxiety & $\begin{array}{l}-0.109 \\
(0.296)\end{array}$ & $\begin{array}{c}0.015 \\
(0.133)\end{array}$ \\
\hline Sadness & $\begin{array}{c}0.010 \\
(0.449)\end{array}$ & $\begin{array}{c}-0.496^{* *} \\
(0.202)\end{array}$ \\
\hline Post length & $\begin{array}{c}0.329^{* * *} \\
(0.043)\end{array}$ & $\begin{array}{c}0.090^{* * *} \\
(0.019)\end{array}$ \\
\hline Time since posted & $\begin{array}{c}0.010^{* * *} \\
(0.001)\end{array}$ & $\begin{array}{l}0.0003 \\
(0.001)\end{array}$ \\
\hline Constant & $\begin{array}{c}-2.623^{* * *} \\
(0.234)\end{array}$ & $\begin{array}{l}-0.161 \\
(0.105)\end{array}$ \\
\hline $\mathrm{N}$ & 1,516 & 1,516 \\
\hline $\mathrm{R}^{2}$ & 0.283 & 0.065 \\
\hline Adjusted $\mathrm{R}^{2}$ & 0.276 & 0.056 \\
\hline Residual Std. Error $(\mathrm{df}=1501)$ & 1.084 & 0.487 \\
\hline F Statistic $(\mathrm{df}=14 ; 1501)$ & $42.303^{* * *}$ & $7.435^{* * *}$ \\
\hline
\end{tabular}

${ }^{*} \mathrm{p}<.1 ;{ }^{* *} \mathrm{p}<.05 ;{ }^{* * *} \mathrm{p}<.01$

Note: We transformed our two dependent variables into the log format before we ran this model. For variable Hubei, we coded it 1 if the province field a user filled in is Hubei Province, and 0 otherwise. Conspiracy posts are the reference group for the variable "Debunking posts". 


\section{Appendix E: Regression table output for Figure 4}

Associations of Debunking to User Participation and Mobilization - Full Model

\begin{tabular}{|c|c|c|}
\hline & $\begin{array}{c}\text { Participation } \\
\text { (1) }\end{array}$ & $\begin{array}{c}\text { Mobilization } \\
\text { (2) }\end{array}$ \\
\hline Debunking posts & $\begin{array}{l}-0.113 \\
(0.273)\end{array}$ & $\begin{array}{l}-0.014 \\
(0.124)\end{array}$ \\
\hline Scientists & $\begin{array}{l}-0.141 \\
(0.133)\end{array}$ & $\begin{array}{l}-0.035 \\
(0.061)\end{array}$ \\
\hline Nonscientist sources & $\begin{array}{c}-0.105 \\
(0.096)\end{array}$ & $\begin{array}{c}0.016 \\
(0.044)\end{array}$ \\
\hline Nature/Unknown origin & $\begin{array}{l}-0.110 \\
(0.114)\end{array}$ & $\begin{array}{l}-0.025 \\
(0.052)\end{array}$ \\
\hline Human-synthesis & $\begin{array}{c}0.111 \\
(0.086)\end{array}$ & $\begin{array}{c}0.022 \\
(0.039)\end{array}$ \\
\hline Lab-edited & $\begin{array}{c}0.044 \\
(0.087)\end{array}$ & $\begin{array}{l}-0.020 \\
(0.040)\end{array}$ \\
\hline Bioweapon & $\begin{array}{l}-0.033 \\
(0.113)\end{array}$ & $\begin{array}{c}-0.115^{* *} \\
(0.052)\end{array}$ \\
\hline Other conspiracy types & $\begin{array}{l}-0.294 \\
(0.199)\end{array}$ & $\begin{array}{c}0.083 \\
(0.091)\end{array}$ \\
\hline China responsibility only & $\begin{array}{c}0.282^{* * *} \\
(0.089)\end{array}$ & $\begin{array}{l}-0.018 \\
(0.041)\end{array}$ \\
\hline US responsibility only & $\begin{array}{c}0.226^{* * *} \\
(0.086)\end{array}$ & $\begin{array}{l}-0.024 \\
(0.039)\end{array}$ \\
\hline Male & $\begin{array}{c}-0.152^{*} \\
(0.081)\end{array}$ & $\begin{array}{c}-0.071^{*} \\
(0.037)\end{array}$ \\
\hline Influencer & $\begin{array}{c}0.045 \\
(0.122)\end{array}$ & $\begin{array}{c}0.163^{* * *} \\
(0.055)\end{array}$ \\
\hline Organization & $\begin{array}{c}-0.664^{* * *} \\
(0.138)\end{array}$ & $\begin{array}{l}0.157^{* *} \\
(0.063)\end{array}$ \\
\hline Number of followers & $\begin{array}{c}0.267^{* * *} \\
(0.023)\end{array}$ & $\begin{array}{c}0.004 \\
(0.010)\end{array}$ \\
\hline Debunking posts:Scientists & $\begin{array}{l}-0.215 \\
(0.215)\end{array}$ & $\begin{array}{l}0.226^{* *} \\
(0.098)\end{array}$ \\
\hline Debunking posts:Nonscientist sources & $\begin{array}{l}-0.024 \\
(0.187)\end{array}$ & $\begin{array}{c}0.040 \\
(0.085)\end{array}$ \\
\hline Debunking posts:Nature/Unknown origin & $\begin{array}{c}-0.033 \\
(0.163)\end{array}$ & $\begin{array}{l}-0.011 \\
(0.074)\end{array}$ \\
\hline Debunking posts:Human-synthesis & $\begin{array}{l}-0.182 \\
(0.130)\end{array}$ & $\begin{array}{l}-0.061 \\
(0.059)\end{array}$ \\
\hline Debunking posts:Lab-edited & $\begin{array}{l}-0.115 \\
(0.137)\end{array}$ & $\begin{array}{c}0.015 \\
(0.062)\end{array}$ \\
\hline Debunking posts:Bioweapon & $\begin{array}{l}-0.202 \\
(0.226)\end{array}$ & $\begin{array}{c}0.099 \\
(0.103)\end{array}$ \\
\hline Debunking posts:Other conspiracy types & $\begin{array}{c}0.026 \\
(0.282)\end{array}$ & $\begin{array}{c}0.060 \\
(0.128)\end{array}$ \\
\hline Debunking posts:Male & $\begin{array}{c}-0.301^{* *} \\
(0.128)\end{array}$ & $\begin{array}{c}0.013 \\
(0.058)\end{array}$ \\
\hline Debunking posts:Number of followers & $\begin{array}{c}0.077^{* * *} \\
(0.027)\end{array}$ & $\begin{array}{l}-0.001 \\
(0.012)\end{array}$ \\
\hline Other controls included & & \\
\hline $\begin{array}{l}\text { Observations } \\
\mathrm{R}^{2} \\
\text { Adjusted } \mathrm{R}^{2} \\
\text { Residual Std. Error }(\mathrm{df}=1483) \\
\text { F Statistic }(\mathrm{df}=32 ; 1483)\end{array}$ & $\begin{array}{c}1,516 \\
0.310 \\
0.295 \\
1.069 \\
20.846^{* * *}\end{array}$ & $\begin{array}{c}1,516 \\
0.080 \\
0.060 \\
0.486 \\
4.023^{* * *}\end{array}$ \\
\hline
\end{tabular}

Note: We transformed our two dependent variables into the log format before we ran this model. For Other conspiracy types, we merged $5 G$ and GMO into this category. For China responsibility only, we coded it 1 if a post assigned responsibility to China but not to any other entities and 0 otherwise. For U.S. responsibility only, we coded it 1 if a post assigned responsibility to the United States but not to any other entities, and 0 otherwise. For variables Scientists and Non-scientist sources, both came from a factor variable that has three levels: the reference level is no source is cited in a post, the second level is a post cited scientists/scholars, and the third level is a post cited other non-scientist sources. 


\section{Appendix F: Distribution of individual narratives}

We examined the individual narratives of each conspiracy related post by looking into the distribution of the combination of our two main hand-labelled variables: origin type and responsibility attribution since these two elements constitute the main part of a post's content. From the table below, we can see that individual narratives mainly consist of responsibility attribution to the United States and China when discussing the origin of COVID-19. There is not much variation in individual narratives.

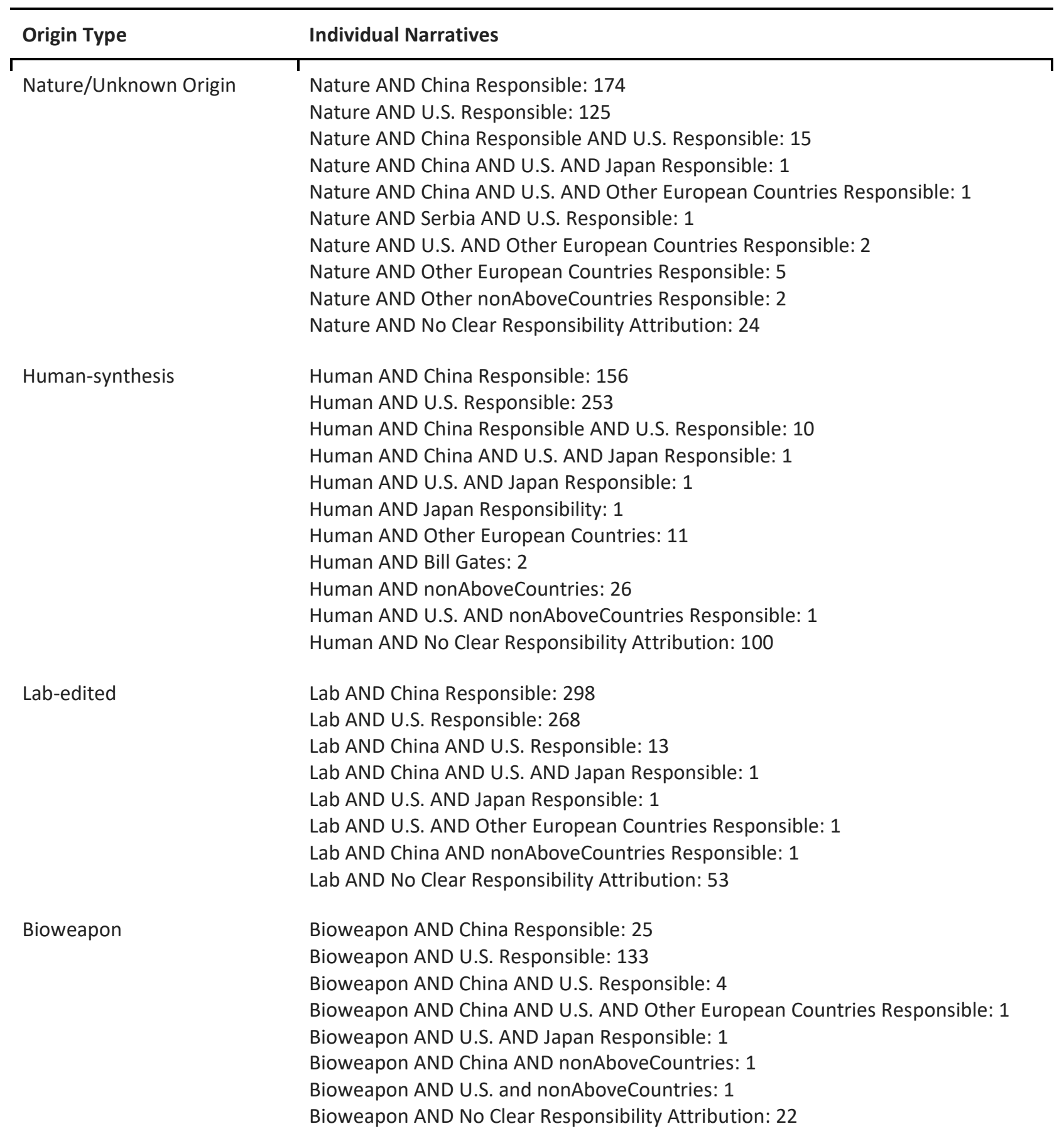


5G
5G AND China Responsible: 14

5G AND U.S. Responsible: 13

5G AND Other European Countries Responsible: 4

5G AND No Clear Responsibility Attribution: 44

GMO AND U.S. Responsible: 6

GMO and No Clear Responsibility Attribution: 1 


\section{Appendix G: Examples of conspiracy posts and debunking posts}

The table below provides examples (in Chinese and in English translation) for conspiracy posts and debunking posts. In this paper, we define conspiracy posts as those that spread conspiracies about the origins of COVID-19. We define debunking posts to broadly include any posts that disapprove, disagree and refute such conspiracies, either with or without providing evidence. The first example of debunking post refutes conspiracy with evidence by stating that people from other countries also got COVID-19. The second and the third example under debunking posts refute conspiracy without using evidence. As we can see that the post authors denounced the conspiracy by saying it is totally nonsense. We did not fact check to verify whether the evidence used in these debunking posts are true.

We also provide the Weibo screenshots of conspiracy posts and debunking posts (in Chinese and in English) after the table.

\begin{tabular}{|c|c|c|}
\hline Post & 例子 (in Original Chinese) & Examples (English Translation) \\
\hline & 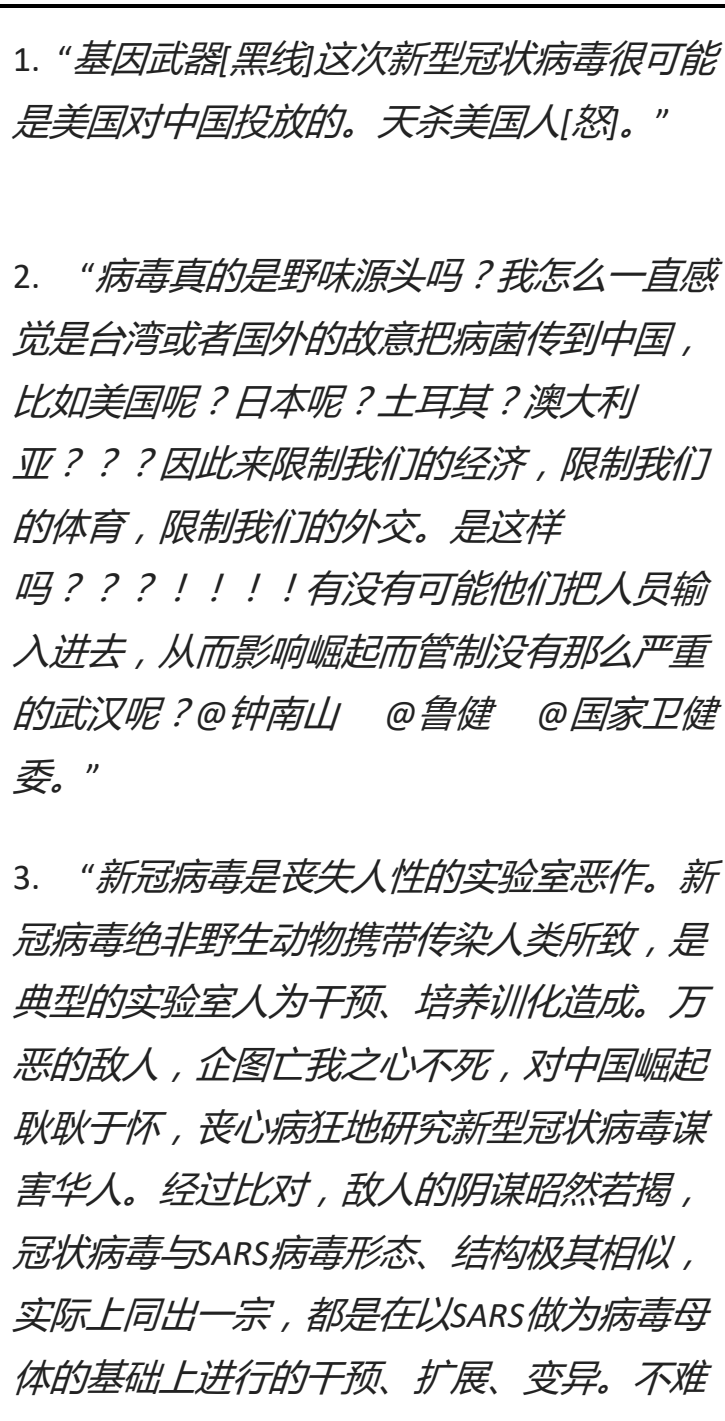 & $\begin{array}{l}\text { 1. "Genetic weapons[blackface]. This new } \\
\text { coronavirus is likely to be launched by the } \\
\text { United States in China. Damn the } \\
\text { Americans[anger]." } \\
\text { 2. "Is the virus originated in wildlife? Why do } \\
\text { I always feel that Taiwan or other countries } \\
\text { deliberately spread the virus to China, such as } \\
\text { the United States? How about Japan? Turkey? } \\
\text { Australia? ?? So to restrict our economy, } \\
\text { restrict our sports, restrict our diplomacy. Is } \\
\text { that right? ? !!!! Is it possible that they } \\
\text { imported infected cases into China, thus } \\
\text { affecting the rise of Wuhan? @Zhong } \\
\text { Nanshan @Lu Jian @Chinese National Health } \\
\text { Commission." }\end{array}$ \\
\hline
\end{tabular}


发现，SARS和冠状病毒都是出自同一实验室 的恶劣创作，是丧失人性的卑㾂实验！中国 人民必须擦亮眼晴，认清帝国主义本色，揭 露敌人的阴谋论计，与丧心病狂的敌人开展 针锋相对的斗争。”

1. “又一个阴谋论破了，病毒不是针对亚洲 N/I///澎湃新闻:【日本政府：\#钻石公主号 由阝轮新增41例新冠肺炎\#，其中21人为日 籍】日本厚生劳动省>日发布新确认感染新 型冠状病毒的41人国籍，具体为21名日本 人，8名美国人、5名澳大利亚人、5名加拿 大人、1名阿根廷人、1名英国人。”

Debunking posts
2. “\#武汉病毒所目前零感染\# 笑死了。用脚 想想，零号病人。哈哈哈哈。可真会编。”

3. “一个做筮菌体的已毕业多年的学生，居 然被阴谋论分子说是零号病人，还这么多人 信......可见大家也是真的不懂...... 你们记住 了，签菌体是感染细菌的病毒! 不能感染植 物，动物！!！下次编的时候，记得找个做 人源病毒的，至少是哺乳动物源吧?\#武汉 加油\#\#武汉病毒所目前零感染\#\#武汉病毒所 \#\#中国加油\#\#造谣一张嘴, 辟谣跑断腿\#”
SARS and coronavirus are both bad creations from the same laboratory, and they are dehumanizing and humble experiments! The Chinese people must keep their eyes open, recognize the true nature of imperialism, reveal the enemy's conspiracy and tricks, and wage a tit-for-tat struggle against the frenzied enemy."

1. "Another conspiracy theory is debunked. The virus is not aimed at Chinese. $/ / / / / /$ The Paper: [Japanese Government: \# Announced the nationalities of 41 people newly confirmed to be infected with the new coronavirus, specifically 21 Japanese, 8 Americans, 5 Australians, 5 Canadians, 1 Argentine, and 1 British."

2. "\#Currently Zero Infection in Wuhan Institute of Virology\# Laughed to death. Think with your feet, "index case"?. Hahahaha. Totally stuff and nonsense."

3. "A student majored in bacteriophage, and who graduated many years ago, was accused of being an"index case" by conspiracy theorists, and so many people believe... It shows that everyone really doesn't understand... You remember, bacteriophages are viruses that infect bacteria! Can not infect plants, animals!!! When you talk nonsense next time, remember to find a human-derived virus, at least of mammalian origin, right?"\#Stay strong, Wuhan\#\#Currently Zero Infection in Wuhan Institute of Virology\#Stay strong, China\#\#Easy to Fabricate Rumor, However, Hard to Debunk it\#." 
Conspiracy Posts Example 1:

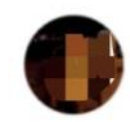

1月29日 19:00 来自 荣新较玩4C

基因武器 -1 这次新型冠状病毒很可能是美国对中国投放的。天杀美国人○?

上饶·上饶县

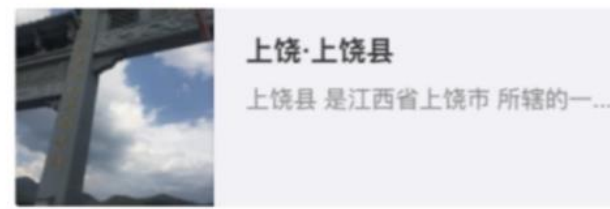

Genetic weapons[blackface]. This new coronavirus is likely to be launched by the United States in China. Damn the

Americans[anger]

Conspiracy Posts Example 2:

1月31日 00:11 来自 HUAWEI Mate 20

病毒真的是野味源头吗? 我怎么一直感觉是台湾或者国外的故意把病菌传到中 国, 比如美国呢? 日本呢? 土耳其? 澳大利亚? ? ? 因此来限制我们的经济, 限 制我们的体育, 限制我们的外交。是这样吗? ? ? ! ! ! ! 有没有可能他们把人 员输入进去, 从而影响崛起而管制没有那么严重的武汉呢? @钟南山@鲁健 @国 家卫健委

Is the virus originated in wildlife? Why do I always feel that Taiwan or other countries deliberately spread the virus to China, such as the United States? How about Japan? Turkey? Australia? ?? So to restrict our economy, restrict our sports, restrict our diplomacy. Is that right? ? ?!!!! Is it possible that they imported infected cases into China, thus affecting the rise of Wuhan? @Zhong Nanshan @Lu Jian @Chinese National Health Commission. 


\section{Conspiracy Posts Example 3:}

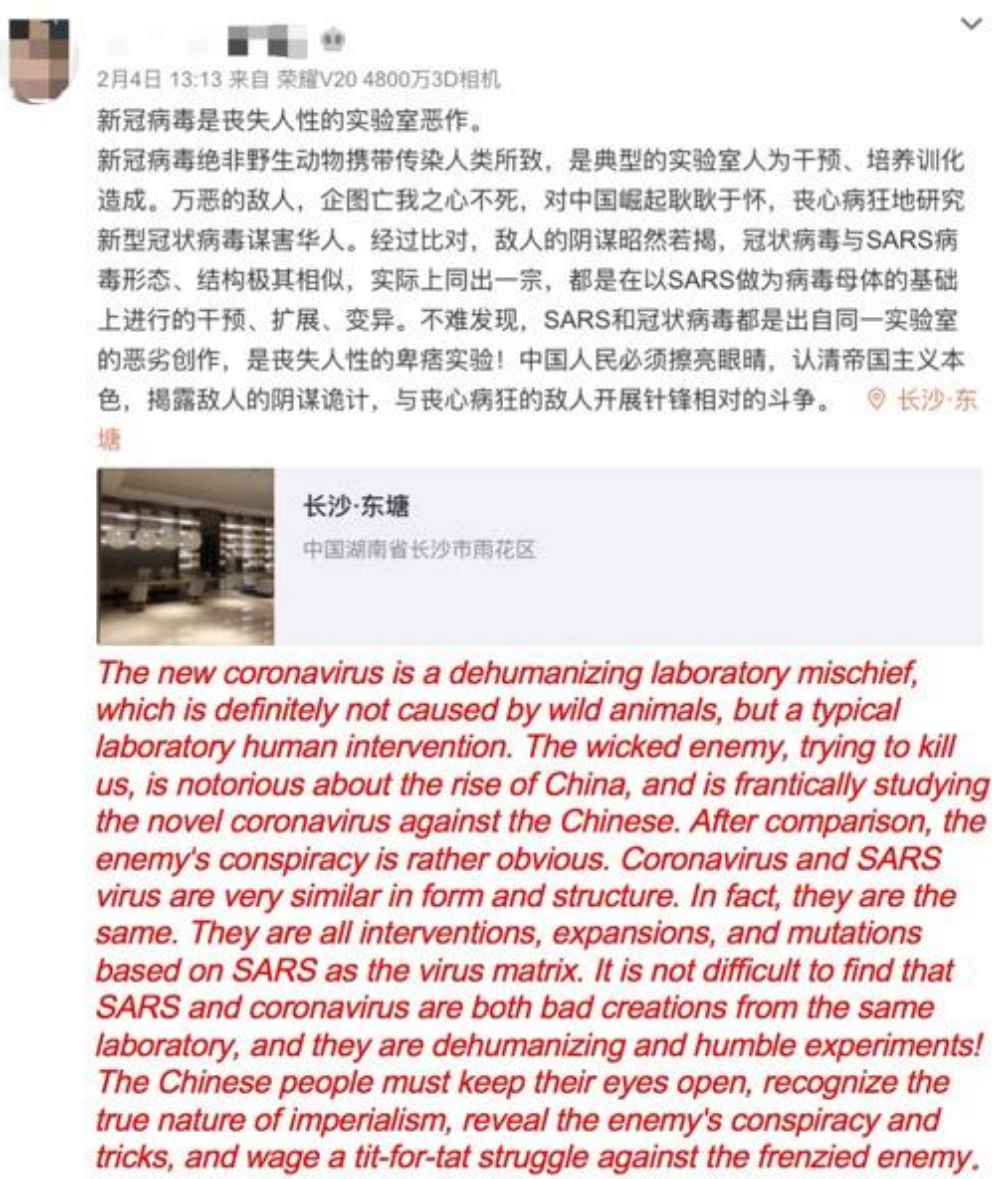

Debunking Posts Example 1:

2月7日 22:22 来自 Android客户端

又一个阴谋论破了, 病毒不是针对亚洲人 $I I I I /$ 澎湃新闻: 【日本政府：\#钻石公主号 邮轮新增41例新冠肺炎\#, 其中 21 人为日籍】 日本厚生劳动省7日发布新确认感染 新型冠状病毒的 41 人国籍, 具体为 21 名日本人, 8 名美国人、5名澳大利亚人、 5 名加拿大人、1名阿根廷人、1名英国人。02olfKR07。页链接 


\section{Debunking Posts Example 2:}

2月16日 12:08 来自 Redmi K20 Pro 真旗船

\#武汉病毒所目前零感染\#笑死了。用脚想想, 零号病人。哈哈哈哈。可真会编。

\#Currently Zero Infection in Wuhan Institute of Virology\# Laughed to death. Think with your feet, "index case"?. Hahahaha. Totally stuff and nonsense.

\section{Debunking Posts Example 3:}

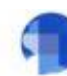

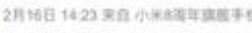

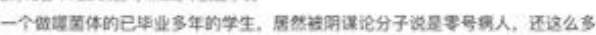

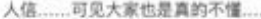

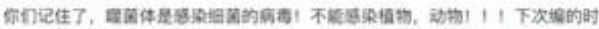

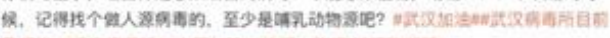

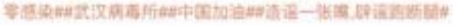

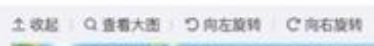

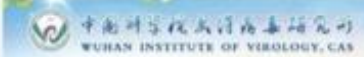

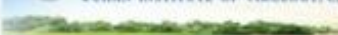

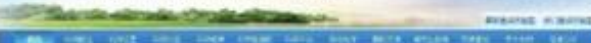

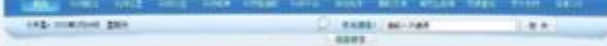

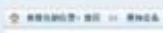

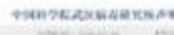

(16)

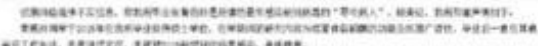

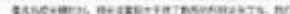
$r$ ro. - mexia

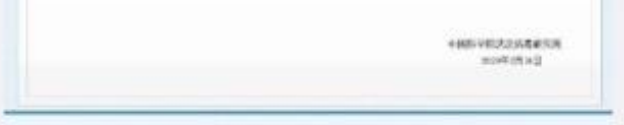

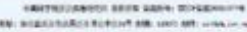

A student majored in bacteriophage, and who graduated many years ago, was accused of being an"index case" by conspiracy theorists, and so many people believe... It shows that everyone really doesn't understand... You remember, bacteriophages are viruses that infect bacteria! Can not infect plants, animals! !! When you talk nonsense next time, remember to find a humanderived virus, at least of mammalian origin, right?"\#Stay strong, Wuhan\#\#Currently Zero Infection in Wuhan Institute of Virology\#Stay strong, China\#\#asy to Fabricate Rumor, However, Hard to Debunk it\#. 